\title{
COVID 19 and Increased Security Challenges in Northern Nigeria: Interrogating Armed Banditry in Northwestern Nigeria
}

\author{
Noah Echa Attah', Usman Sambo², Babayo Sule ${ }^{3}$, Muhammad A. Bello ${ }^{4}$, M. Yoserizal \\ Saragih $^{5}$ \\ ${ }^{1}$ Department of History and Diplomatic Studies, Federal University of Kashere Gombe, Gombe State Nigeria \\ ${ }^{2}$ Department of Public Administration, Yobe State University, Damaturu, Nigeria \\ ${ }^{3}$ Department of Political Science, Federal University of Kashere Gombe, Gombe State Nigeria \\ ${ }^{4}$ Department of History, Gombe State University \\ ${ }^{5}$ Universitas Islam Negeri Sumatera Utara, Indonesia \\ neattah@gmail.com, ussambo2@gmail.com, babayosule@gmail.com, muhammadbello050@gmail.com
}

\section{Abstract}

The COVID 19 pandemic has become a global health issue that now intersects with security issues, especially in African countries. The outbreak of the virus in Africa has halted political, economic and social activities, including countering armed violence. Nigeria is one of the African countries that is faced with security challenges, ranging from Boko Haram insurgency, rural banditry, farmers-herders clash, kidnapping, robbery to piracy among others. However, much attention has concentrated on mitigating the spread of COVID 19 pandemic and the provisions of palliatives to cushion the effects of the abrupt stoppage of formal and informal economic activities. This study examines the intersections between the pandemic and armed banditry in Northwestern. It appears that armed bandits have intensified attacks on communities, against the background of government's anti-COVID policy. Government has equally re-strategized in responding to the bandits' attacks. The study gathered data from documented sources and media reports and were analyzed, using content analysis. The study observed that the armed bandits used the COVID 19 lock down policy to increase attacks on some communities, thereby providing a complex dimension to rural banditry in Northwestern Nigeria. This led to increased air and land offensive by the Nigerian military against the bandits. This study recommends among others that government should increase surveillance and adopt strict measures on movements to curtail the activities of the bandits.
Keywords

banditry, COMD19, military, Ngeria; security

\section{Introduction}

The novel Coronavirus also known as "COVID 19" was declared a global pandemic by the World Health Organisation (WHO) in January, 2020 (Osler, 2020). The virus emanated from the industrial city of Wuhan in China with cases and deaths, untamed by scientific remedies. Within one month, COVID 19 spread across the continents of the world, infecting millions and leaving hundreds of thousands of people dead (Zizek, 2020). Part of the consequences are that economies were sharply affected, social conditions deteriorated worldwide, collective global security suffers setback, and global activities almost stopped (Hruby, 2020). Several efforts from scientific perspective to providing remedies indicated progress, but not a breakthrough (Wang, et al, 2020; He, et al, 2020; 
SIASAT Journal of Social, Cultural and Political Studies, 6 (1) January 2021, 33-44

ISSN: 2721-7469 (Print), 2721-7450 (Online)

Noah Echa Attah, Usman Sambo, Babayo Sule, Muhammad A. Bello, M. Yoserizal Saragih: COVID 19 and Increased Security Challenges in Northern Nigeria: Interrogating Armed Banditry in Northwestern Nigeria https://siasatiournal.com/index.php/siasat

Liang, 2020; Chen et al. 2020, Rosberg et al. 2020; Grant et al. 2020 and Joseph et al. 2020).

The virus hit the American, European and Asian countries harder in terms of reported cases deaths, but Africa suffers more economically and socially due to its fragility (Pichler, Skutnik, Vlad, Shahri, \& Ridwan, 2021). Africa, which is the second populous continent after Asia is the most impoverished in terms of poverty, diseases, unemployment, insecurity, weak political institutions, malnutrition and hunger and other indicators of poor standard of living (Campbell \& McCaslin, 2020). It is within these socioeconomic and political troubles that COVID 19 emerged in Africa. Nigeria, the biggest country in terms of population and Gross Domestic Product (GDP) in Africa is one of the most affected countries by the spread and impact of COVID 19. Prior to the emergence of COVID 19, the country has been exhibiting poor signs of healthcare in terms of HIV/AIDS prevalence, maternal and infant mortality rate, hunger and malnutrition and malaria among other diseases (WHO, 2020).

Besides, the country has been suffering from protracted cases of insecurity in almost all the 36 states and the Federal capital territory. For example, Boko Haram insurgency has been prevalent in the Northeast geo-political zone in the past 10 years, while the herdersfarmers conflicts hold sway in North central and rural banditry in the Northwest. In the South-South and South-West of Nigeria, there have been cases of kidnapping and cultism, which have claimed several lives. All these pose serious threats to Nigeria's national security (Campbell \& McCaslin, 2020). However, efforts against security challenges were ongoing through military strikes, negotiation and deradicalisation when the COVID 19 broke out in the country. Lock down and inter-state travel bans measures by the government to mitigate the spread of the pandemic appear to have provided the fillip for the escalation of armed banditry, especially in Kaduna, Katsina, Sokoto and Zamfara states of the Northwest Nigeria. It is, therefore, imperative to critically examine the extent of how COVID 19 may have exacerbated armed banditry in the Northwest.

\section{Review of Literatures}

\subsection{Overview of COVID 19 Pandemic}

The COVID 19 pandemic is a global pestilence that became pervasive in nature and character. The virus emanated from China in December, 2019 and quickly spread to other parts of the world. The virus, which is related to difficulty in breathing, transmits through direct or close contact with the carrier. Although, it is not an airborne disease so far, the level of interaction in contemporary world is making the virus easier to spread than the previous global pandemics (Wang et al, 2020). Historically, the world has witnessed about 20 major global pandemics, including the Black Death of 1346-1353, the Flu Pandemic of 1889-1890, the Spanish Flu 1918-1920, the Asian Flu of 1957-1958, the Acquired Immune Deficiency Syndrome (AIDS) pandemic from 1981 to date, the West Africa Ebola of 20142016, and recently the COVID 19 epidemic (Jarus, 2020). Since the COVID 19 pandemic started, the global economy has been experiencing downturn with devastating consequences on economic activities. International political tension has also been heightened by the war of words and blame game between the United States and China over the spread of the virus. Socially, the world is suspended by COVID 19 and governments are raising expenditure, closing schools, stopping commercial activities and social gathering (LiveScience, 2020).

Although, accurate figures are difficult to come by, as at $27^{\text {th }}$ January, 2021 reported global cases stood at 101,221,845; 2,177,144 deaths; 73,139,227 recovered cases and 
25,902,474 active cases (Worldometer, 2020). Reports indicate that the United States of America is the most affected and followed by India and Brazil. As at the time of writing this paper, update of the virus globally reveals that the following countries are having the highest cases as indicated in table 1 . This perhaps, might have been influenced by how countries think and their culture towards responding to global issues (Campbell-Phillips, Halder, Campbell, \& Phillips, 2020 and Rahmatirad, 2020).

Table 1. Top Ten Countries with the Highest Cases of COVID 19 at $31^{\text {st }}$ July, 2020

\begin{tabular}{|c|c|c|c|c|c|}
\hline S/No. & Country & Total Cases & $\begin{array}{l}\text { Total } \\
\text { Deaths }\end{array}$ & $\begin{array}{l}\text { Active } \\
\text { Cases }\end{array}$ & Population \\
\hline 1. & USA & $26,092,739$ & 437,891 & $9,819,305$ & $331,161,077$ \\
\hline 2. & India & $10,701,427$ & 153,862 & 175,307 & $1,380,418,989$ \\
\hline 3. & Brazil & $8,949,429$ & 219,203 & 931,571 & $213,394,944$ \\
\hline 4. & Russia & $3,774,672$ & 71,076 & 501,113 & $145,939,731$ \\
\hline 5. & UK & $3,715,054$ & 101,887 & $1,939,231$ & $68,084,411$ \\
\hline 6. & France & $3,106,859$ & 74,456 & $2,811,833$ & $65,353,626$ \\
\hline 7. & Spain & $2,774,014$ & 57,291 & $2,716,723$ & $46,764,883$ \\
\hline 8. & Italy & $2,501,147$ & 86,889 & $2,414,258$ & $60,412,161$ \\
\hline 9. & Turkey & $2,449,839$ & 25,476 & $2,424,363$ & $84,842,191$ \\
\hline 10. & Germany & $2,172,250$ & 52,128 & 251,306 & $83,933,180$ \\
\hline
\end{tabular}

Source: Worldometer 2021

African countries were not affected until two reported cases were confirmed in February, 2020. However, as at 13 July, 2020, almost all African countries have confirmed cases (WHO, 2020). African cases as at $27^{\text {th }}$ January, 2021 indicate 3,482,360 infections, 87,036 deaths, 2,955,778 recoveries and 439,546 active cases (WHO, 2020). The top 10 African countries with the highest confirmed cases are presented below.

Table 2. Top Ten African Countries with the Highest Confirmed Cases as at $31^{\text {st }}$ July, 2020

\begin{tabular}{llll}
\hline S/No. & Country & Total Cases & Region \\
\hline 1. & South Africa & $1,423,578$ & South Africa \\
2. & Morocco & 468,383 & North Africa \\
3. & Tunisia & 200,662 & North Africa \\
4. & Egypt & 163,129 & North Africa \\
5. & Ethiopia & 135,045 & East Africa \\
6. & Nigeria & 124,299 & West Africa \\
7. & Libya & 116,064 & North Africa \\
8. & Algeria & 106,097 & North Africa \\
9. & Kenya & 100,323 & East Africa \\
10. & Ghana & 62,751 & West Africa \\
\hline
\end{tabular}

Source: Shaban (2021)

The World Health Organization (WHO) observed that the confirmed cases in Africa might be more than officially reported due to low level of tests carried out and shortage of equipment. Nigeria declared its first case on $16^{\text {th }}$ February, 2020 when an Italian who returned from an international journey tested positive for the virus. By 26 March, 2020, Nigeria had recorded over 50 confirmed cases. By April, 2020, the government began to enforce lock down inter-state travel bans when 1,300 cases 40 deaths were reported (Campbell et al. 2020). As at $27^{\text {th }}$ January, 2021, the total confirmed cases were 124,299 , 
number of deaths was 1,522, active cases were 22,541 and discharged cases were 99,276 (NCDC, 2020). The first ten states with the highest recorded cases are as below:

Table 3. States in Nigeria with the Highest Confirmed Cases of COVID 19 as at $31^{\text {st }}$ July, 2020

\begin{tabular}{llll}
\hline S/No. & States & Total Cases & Number of Death \\
\hline 1. & Lagos & 46,162 & 294 \\
2. & FCT Abuja & 16,056 & 121 \\
3. & Plateau & 7,648 & 53 \\
4. & Kaduna & 7,399 & 57 \\
5. & Oyo & 5,094 & 72 \\
6. & Rivers & 4,982 & 79 \\
7. & Edo & 3,646 & 135 \\
8. & Ogun & 3,251 & 39 \\
9. & Kano & 2,862 & 74 \\
10. & Delta & 2,244 & 52 \\
\hline
\end{tabular}

Source: Nigerian Centre for Disease Control (NCDC), 2021

\section{Results and Discussion}

\subsection{Rural Banditry in Northwestern Nigeria}

Historically, rural banditry is not a new phenomenon as it was reported in the ancient Greek City States, Medieval Rome and ancient China (Butts, 2016). In the $18^{\text {th }}$ and $19^{\text {th }}$ centuries, rural banditry or armed violence was also found in satellite areas of Central and Eastern Europe and the Balkans. The expanding frontier of the economy in Latin America made banditry to flourish for several decades even in the $21^{\text {st }}$ century (Cassia, 2019). In Africa, rural banditry is palpable and formidable in many countries, particularly in West Africa where countries like Nigeria have recorded some devastating cases in the last one decade. Banditry and armed violence is on the increase, especially in Northwestern Nigeria, one of the most troubled geo-political zones in terms of insecurity in the last one decade. Besides the rural banditry in the Northwestern, there are other security challenges in northern Nigeria. Some of them are Boko Haram insurgency in the Northeast and farmers-herders conflicts in North-central (Le Van, et al, 2018).

Rural banditry is conceived as armed violence with the motive of criminal intention to steal, plunder and waste community resources using either local weapons or sophisticated firearms. Economic factor is seen as one of the motivating drivers of banditry in this geopolitical zone (Okoli \& Ugwu, 2019). The most recent and commonly acts of armed violence and rural banditry are characterized by armed robbery, kidnapping, cattle rustling and village raid as in the cases in Kaduna, Katsina, Sokoto, and Zamfara. Rural banditry in Northwestern Nigeria has reached a disturbing dimension in recent times due to its complex nature and the defying military solution, perhaps because of its irregular manner and character in an ungovernable space. These bandits are often settled in fortified village environments and forests from where they plan, organize and carry out their criminal activities (Okoli, 2019).

Central to the drivers of armed violence in Northwestern Nigeria are ungovernable spaces - remote and arid nature of some locations in the zone with minimal or total absence of governance. This is followed by the prevailing poor indices of socioeconomic situations in the geopolitical zone, which have been abetting the precarious security situation in the area. Other factors that continue to increase and influence banditry in the zone are porous borders, climatic change, trans-national movement and connectivity of 
armed groups in West Africa, poorly equipped and ill-motivated security personnel, low level of intelligence gathering and presumed invisible hands of powerful supporters (Okoli, 2019). It is important to note that armed banditry in the zone started as a localized conflict between farmers and herders, but escalated to become insurmountable violence and posing threat to both national and regional security in Nigeria and other some West African countries. It is also important to note that the rural banditry became so complex between 2014 and 2019 with serious economic and political implications in the run-up to the 2019 General Elections (Suleiman, 2019).

According to the ACAPS Nigeria (2020), about 1,586 lives have been lost to rural banditry and 318,000 displaced. The current wave of banditry began in 2011 as a mild farmer-herder conflict in the Northwest, but became intensified since 2017 with increasing destruction of lives and property. The violence has thus far affected 35 out of 92 local government areas in the four states of Northwest. The banditry continues to escalate due to the activities of illegal mining of gold in the area, which has also pitched the armed groups against the Nigerian state. A report in March, 2020, indicate that more than 210,000 people have been internally displaced and over 35,000 refugees have crossed communal borders of Nigeria into Niger Republic (ACAPS Nigeria, 2020). The most affected states are Kaduna, Zamfara and Katsina states. Ungovernable spaces such as Kamuku, Birnin Gwari, Rugu, Kamara, Kunduma and Sububu forests are used by the bandits as shelter from where they launch attacks on the surrounding communities. In the cause of the attacks, they often rustle cattle, killed people and raped women and children (Suleiman, 2019).

More than 6,319 people were killed between 2011 and 2018, while 190,340 were displaced in Zamfara state alone. In Katsina, over 2, 000 people were killed and 500 communities destroyed, while over 33,000 were displaced (Kola, 2020). Between January and December, 2019 alone, 1,058 people were killed in Zamfara, Kaduna, Katsina, Sokoto and Niger States. In addition, over 10,000 cattle were rustled, 2,688 hectares of arable farming land was lost due to displacement and forceful migration. About 10,000 houses were destroyed and over 147,800 vehicles were lost to the bandits in Zamfara State alone (Hamrouni, 2020). Furthermore, 4,000 people were internally displaced in Kaduna State with scores of thousands of death between November, 2019 and March, 2020 (West Africa Network for Peacebuilding, 2020). The graph below shows the number of fatalities from banditry in Northwestern Nigeria between January and December 2019.

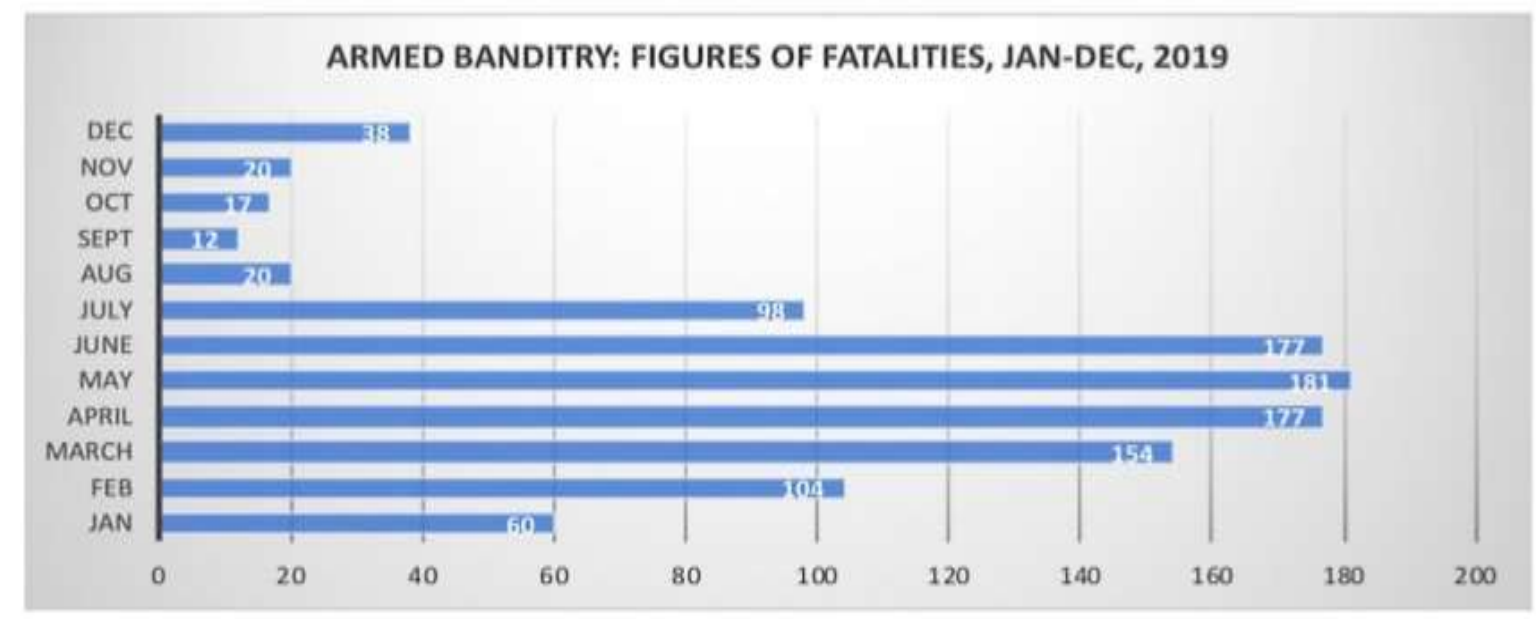

FIG 1: ARMED BANDITRY IN NIGERIA FIGURES OF FATAUITIES (IANUARY-DECEMBER 2019)"

Figure 1. Number of Casualties from Armed Banditry in Northwestern Nigeria between January and December, 2019

Source: Adapted from West Africa Network for Peacebuilding, 2020. 
The above graph shows the extent and manner in which banditry affected lives of the people in Northwestern Nigeria. Already, there is a humanitarian crisis due to the attacks. With the displacement of more than 300,000 people, most of who are farmers, there is a threat to food security. The halted commercial activities in the affected areas have crashed several businesses and small scale enterprises, leading to loss of jobs, and increasing poverty. Women and children, the most vulnerable in the society are left without support due to the death of their breadwinners.

\subsection{COVIID 19 and Rural Banditry in Northwest Nigeria}

In the wake of the outbreak of COVID 19 in Nigeria, the government concentrated its attention on curbing the spread of the pandemic, owing to the nature of the virus and fragile health care services. One of the measures taken by the government was the enforcement of lock down in April, 2020 when the virus seemed to be spreading rapidly. Additionally, a ban on inter-state travels was put in place. Prior to the Federal Government anti-COVID 19 policies, some states such as Lagos, Ogun and Oyo banned inter-state travels. Thus, movements, commercial activities, farming, fishing and social engagements were almost grounded. The anti-COVID 19 measures affected the security situation in the country, particularly in the Northwest where armed bandits took advantage of restriction of movements to attack people in their homes. The attacks led to loss of several lives and property (Kola, 2020).

According to Salem Maddeb Hamrouni, a reporting officer at the United Nations High Commission for Refuge (UNHCR) refugee agency, the armed groups in Northwestern Nigeria became more active during the COVID 19 restrictions to the extent of making the region to appear separate from Nigeria in terms of security governance. They openly enter communities, mostly on speed bikes, carrying AK47 and other deadly weapons with which they attacked their victims unquestioned and unchecked from the Nigerian security architecture. For example, between April and June, 2020, more than 50 major attacks were carried out by the armed bandits in Kaduna, Zamfara, Katsina and Sokoto states (Akinwotu \& Sanyinnawal 2020). Specifically, on 26 May, 2020, heavily armed bandits on motorbikes attacked the village of Sabon Birni, leaving more than 80 people dead and several others injured in one day (Campbell et al. 2020). In fact, it was reported that between April and July, 2020, attacks similar to that of Sabon Birni, were carried out with the loss of over 100 lives (Akinwotu et al. 2020).

Similarly, a report disclosed that between April and July, 2020, over 30,000 refugees crossed the Nigerian border into the Niger Republic with most of them women and children. Despite the lock down on international borders, owing to COVID 19 pandemic, UNHCR ensured that the refugees were allowed entry into the Niger Republic. Currently, the refugees are being relocated to safety where they would be provided with water, food, shelter, access to health care and other basic amenities (Hamrouni, 2020). Similarly, on May 30th, armed bandits numbers 500 on motorbikes with AK 47 attacked several villages in Katsina in which they killed about 18 villagers, including a traditional chief. They confiscated thousands of livestock, especially cattle. This is just part of their several intensified attacks in Kaduna, Katsina, Sokoto and Zamfara while the country was under lock down (Campbell \& McCaslin, 2020).

The armed bandits continued their criminal activities unabated when on 10 June, 2020, they attacked six villages in Katsina State, killing more than 60 people and sacking an entire village. Some residents narrated how the bandits raped women, rustled 200 cattle and looted shops in an operation that lasted for over five hours. These attacks created discord and discontentment, especially in the Northwest where some youths displayed their 
anger through cancelling the celebration of 'Democracy Day'on June 12. They complained that the government failed to demonstrate serious commitment towards alleviating their plights in the manner it has handled the conflict. They further accused the government of paying more attention on COVID 19, which did not kill in four months what was lost to insecurity in less than two months (Campbell \& McCaslin, 2020).

As mentioned earlier, the bandits took the advantage of the lockdown and inter-state travel bans to intensify their attacks. For example, on Saturday 19 April, 2020, bandits attacked several villages in Katsina and killed more than 50 people. The Police spokesman in the area disclosed that more than 300 armed men carried out the attacks, using AK47 weapon. It was reported that the bandits demanded the villagers to surrender the food items and relieve materials distributed to them as palliatives for COVID 19 pandemic (International Crisis Group, 2020). The attacks aggravated the security challenges and by extension, national security of the Africa's most populous country, which may have effects on regional security challenges in West Africa (Al Jazeera Africa, 2020). It has been estimated that more than 8,000 lives were lost to armed banditry since it started in Northwestern Nigeria.

It has been suggested that this figure is likely to double if adequate measures are not taken, due to the increasing banditry attacks during the few months of COVID 19. For example, between April and June, 2020, which were parts of the COVID 19 lockdown months, more than 100 lives were lost to armed bandits in Katsina state alone, the home state of President Buhari. In the course of the attacks, the bandits targeted the relieve materials and palliatives that were distributed to the members of the communities. The palliatives that should have provided succor and relieve to the people due to the effects of the lockdown, became handouts for the bandits. The wider implication of the situation is that the people are at the risk of double jeopardy of bandits and COVID 19.

It is now a major concern that the bandits move about freely and carried out deadly attacks under lockdown and inter-state travel bans without serious intervention from the state security apparatus. It is also worrisome to note that with the number of security personnel in this zone, ranging from the Nigerian military to the police, the Nigerian state has failed to put an end to the activities of "irregular soldiers" of the bandits just as it is with the Boko Haram in the Northeast of Nigeria. The Nigerian state should have paid special attention to this troubled zone during the COVID 19 lockdown by providing special palliatives against the background of humanitarian crisis caused by the effect of armed banditry. Although, government officials claimed millions of dollars was spent to provide palliatives during the COVID 19 as elsewhere, they were not more than tokenism (Hruby, 2020).

It is important to note that such emergency situation equally deserves palliatives, which should be "security" inclusive, without which the palliatives would be lost to the bandits as it actually did. The absence of honest commitment by the state in the fight against armed banditry may have exacerbated it during the COVID 19 as it is with the insurgency in the Northeast, despite the presence of the military there. It has been suggested that corruption and weak security architecture in the country could be attributed to the increased attacks even during COVID 19 lockdown, but the former appears to play more significant role in the security quagmire (Onwujekwe, Orjiakor \& Agwu, 2020). It is in this sense that it has become difficult to exonerate the Nigerian security high command, security personnel, the state and some traditional institutions from the blame of the crisis because of unconfirmed cases of corruption. It is also against this background that Sule et al, (2017) have observed that the Nigerian security sector has been converted into moneymaking venture since 2013 without much regard to the effects on lives and property. 


\subsection{The Responses of Government to Rural Banditry and COVID 19}

The Federal Government of Nigeria is not unaware of the linkage between illegal mining and rural banditry in some Northwestern states, especially, Zamfara. Thus, the government suspended all mining activities in the State and in the zone at large. However, there were some allegations of sponsorship of the bandits by illegal mining cabals in order to divert government' attention to the security situation rather than the illicit mining (Okoli, 2019). In fact, the government has so far been pre-occupied with security challenges in the Northwest geo-political zone as exemplified in the establishment of some code-named security outfits in the zone. For example, between January and April, 2019, a number of operations were executed by the government security operatives in Northwestern Nigeria, including, Operation Harbin Kunama, Operation Diran Mikiya and Operation Puff Adder.

The government has also spent billions of Naira in the process. In fact, Zamfara state government alone has spent over 17 billion in funding security operations to tackle the challenges of banditry (Suleiman, 2019). It is pertinent to note that many communities, farmlands and settlements have been deserted despite ongoing military operations in the region. It is, therefore, surprising to note that despite Federal Government's military response in mitigating banditry in Northwestern Nigeria, armed banditry continues to be on the increase in Zamfara, Sokoto, Katsina and Kaduna, especially during the COVID 19. The situation has raised a lot of concerns about the effectiveness and methods of counterarmed banditry approach in the zone.

Although some measures, such as the ban on the use of motorbikes, were put in place, because they are often used by the bandits in the course of their attacks, the ban could not counter banditry. The lockdown in the emergence of COVID 19 set the clear path for the bandits to attack with impunity. In addition, the federal and state governments in the affected region attempted to mitigate the crisis through some peace-building initiatives, such as dialogues, amnesty, the use of traditional rulers, community policing, community watch dogs, Civil Society Organisations (CSOs) and intelligence gathering, the results are yet to be seen (International Crisis Group, 2020 and West Africa Network for Peacebuilding, 2020).

When the Nigerian government appears to realize how damaging the banditry is to its military reputation, the security service chiefs went to Katsina, Zamfara and other Northwestern states in June, 2020 to examine possible security lapses responsible for the escalation of banditry, despite the lockdown and inter-state travel bans. The Nigerian security decided that since there was a total lockdown and travel bans, except within the confine of the localities, highway travelers might be bandits. The military further decided to intensify air strikes on the locations of the bandits between June and July, 2020, leading to the killings of more than 300 bandits and some of their camps were destroyed and their logistics shattered (Orjinmo, 2020). The Nigerian security has also embarked on combing the forest for the remaining bandits (Market Watch culled from Xinhua News, 2020). If truly the bandits are staying in those forests and the security operatives are genuinely combing the forests as they have declared, it will go a long way in minimising their strength of attacks and havocs in the zone (Al Jazeera Africa, 2020). But it could be recalled that such report had been severally presented before in the case of Boko Haram insurgents in Sambisa forests, which later turned out to be untrue (Sule et al. 2019).

It is important to note here that the reactions of the Nigerian government appear to be soft in handling the bandits, a situation that might become unmanageable and unending like Boko Haram. If the air strike is a plausible remedy, it should have been deployed since April, 2020 when the bandits intensified their attacks during lockdown, instead of waiting 
till the loss of many lives and property. Already, some analysts have viewed the approach as one-sided and ineffective, due the absence of reliable intelligence gathering, devoid of complicity. The bandits relied on intelligence and informants' sources to perpetrate their attacks without being countered in most cases. If the security operatives could pay attention to intelligence gathering, the attacks could be overcome or drastically reduced. It is, therefore, imperative that counter-armed banditry strategies should be based on reliable and feasible approach.

\section{Conclusion}

The study has examined the disturbing issue of armed banditry against the background of the challenges of COVID 19 pandemic in Northwest Nigeria. This has become necessary because the challenges of national security in Nigeria may extend to other West African countries. It was identified that the COVID 19 outbreak in Nigeria was premised on already fragile and fragmented state with security challenges. While measures were taken to mitigate the effects of the virus and at the same time counter armed banditry in Northwestern Nigeria, the bandits took advantage of the lockdown and inter-state travel bans to intensify their attacks. The roles of illegal mining and corruption by state officials, military personnel and even traditional rulers have been fingered as some of the major drivers of armed banditry in the zone. The study concludes that the attacks by bandits during COVID 19 pandemic further worsened humanitarian situation in the affected region, thereby leading to trans-border refugees, increase in death tolls, depletion of farm lands with the consequences on food security.

It is, therefore, recommended that security agencies should pay more attention on surveillance and intelligence gathering due to the ungovernable nature of the forests that shelter the bandits. The government must be sincere in providing the needed equipment and compensations that will motivate security operatives. Community policing and information gathering as well as cutting off the sources of funding, weapons, logistics and movements of bandit groups, among others should be used to weaken them into submission. Finally, it is suggested as a long term panacea that policymakers should design programmes that will ensure equality and equity in the allocation and distribution of resources in order to mitigate poverty in the Northwest and other parts of Nigeria. The elimination or reduction of poverty will no doubt, contribute to the reduction of insecurity and increasing armed groups in Nigeria.

\section{References}

ACAPS Nigeria (2020). Northwest Banditry. ACAPS. Retrieved from https://www.acaps.org/country/nigeria/crisis/northwest-banditry on 14th July, 2020 at 11: $29 \mathrm{pm}$.

Al Jazeera Africa (2020). Armed Bandits Killed at Least 47 in Nigeria's Katsina State: Police.

Al Jazeera.Retrieved from https://www.aljazeera.com/news/2020/04/armed-bandits-kill47-nigeria-katsina-state-police-200419183056608.html on 14th July, 2020 at 11:43 pm.

Akinwotu, E. \& Sanyinnawal, H.S. (2020). "Waves of 'Bandit' Massacres Rupture Rural Life in 
North-West Nigeria”. The Guardian. Retrieved from https://www.theguardian.com/world/2020/jun/03/waes-of-bandit-massacres-rupturerural-life-in-north-west-nigeria on 14th July, 2020 at 11:33 pm.

Butts, E. (2016). Bandits and Renegades: Historical True Crime Stories. Toronto, Canada: VP Publications.

Campbell, J. \& McCaslin, J. (2020). "How Nigeria Has Responded to COVID-19 So Far".

Council On Foreign Relations. Retrieved from https://www.cfr.org/blog/how-nigeria-hasresponded-covid-19-so-far.

Campbell, J. \& McCaslin, J. (2020). "Bandits and Jihadi Attacks Span Northern Nigeria".

Council On Foreign Relations. Retrieved from https://www.cfr.org/blog/bandit-and-jihadiattacks-span-northern-nigeria on 14th July, 2020 at 11:40 pm.

Campbell, J. \& McCaslin, J. (2020). "Recent Flare Up in Violence Across Northwestern Nigeria". Council on Foreign Relations. Retrieved from https://www.cfr.org/blog/recent-flare-violence-across-northwestern-nigeria on 14th July, 2020 at 11:55 pm.

Campbell-Phillips, S., Halder, D.P., Campbell, S., \& Phillips, D. (2020). "Cross Cultural Differences in Cognition: A Study on How Culture Affects the Way We Think". Siasat Journal. 5(3), 9-15.

Cassia, P., S. (2019). Banditry. Encyclopedia.Com. Retrieved fromhttps://www.encyclopedia.com/history/modern-europe/ancient-history-middleages-and-feudalism/banditry on 14th July, 2020 at 9:45 pm.

Chen, Z., Hu, J., Zhang, Z., Jiang, S., Han, S., Yan, D., Zhuang, R., Hu, B., \& Zhang, Z. (2020).

Efficacy of Hydroxychloroquine in Patients with COVID-19: Results of a Randomized Clinical Trial. Wuhan, China: Renmin Hospital of Wuhan University. Available at CC-BY-NC-ND 4.0 International license.

Grant, W.B., Lahore, H., McDonnell, S.L., Baggerly, C.A., French, C.B., Aliano, J.L., \&

Bhattoa, H.P. (2020). "Evidence that Vitamin D Supplementation Could Reduce Risk of Influenza and COVID-19 Infections and Deaths". Nutrients 2020, 12, 988; doi:10.3390/nu12040988. MPDI. Available at www.mdpi.com/journal/nutrients.

Hamden, R.H. (2019). Psychology of Terrorists: Profiling and Counter Action. New York, USA:CRC Taylor \& Francis Group.

Hamrouni, S.M. (2020). "More than 30, 000 Refugees Flee Violence in Northwest Nigeria in Last Two Months Alone". UNHCR, The UN Refugee Council. Retrieved from https://www.unhcr.org/news/stories/2020/6/5ef5e99e4/30000-refugees-flee-violencenorthwestern-nigeria-months-alone.html on 14th July, 2020 at 11:37 am.

He, G., Pan, Y., \& Tanaka, T. (2020). COVID-19, City Lockdown, and Air Pollution: Evidence from China. Hong Kong, Hong Kong University of Science and Technology. Available at ttps://doi.org/10.1101/2020.03.29.20046649.

Hochberg, M.E. (2020). Importance of Suppression and Mitigation Measures in Managing COVID 19 Outbreaks. Montpellier, France: available under the CC-BY-NC-ND 4.0 International license

Hruby, A. (2020). "A Rough Road Ahead for Nigeria". Atlantic Council. Retrieved from https://www.atlanticcouncil.org/blogs/africasource/a-rough-road-ahead-for-nigeria/

International Crisis Group (2020). Violence in Nigeria's Northwest: Rolling Back the Mayhem. Brussels, Belgium: International Crisis Group.

Jarus, O. (2020). "20 of the Worst Epidemics and Pandemics in History". LiveScience. Retrieved from https://www.livescience.com/worst-epidemics-and-pandemics-inhistory.html on 14th July, 2020 at 10:09 pm. 
Johnson, J.L. (2018). The Marines Counter Insurgency and Strategic Culture: Lessons Learned and Lost in America's War. George Town, USA: George Town University Press.

Joseph, T., \& Ashkan, M. (2020). International Pulmonologists Consensus on COVID 19. Kerala, India: Amrita Institute of Medical Sciences.

Kola, O. (2020). "Bandits Attack Kills 'Many' in NW Nigeria: Governor". AA ICC. Retrieved from https://www.aa.com.tr/en/africa/bandits-attack-kills-many-in-nwnigeria-governor/1856542 on 14th July, 2020 at 11:49 pm.

Le Van, A., C., Hassan, I., Kwaja, C., \& Nwankwor, C. (2018). Study on Marginalized Groups in the Context of ID in Nigeria National Identification for Development (ID4D) Project. Abuja, Nigeria: Centre for Democracy and Development (CDD).

Liang, T. (2020). Handbook of COVID 19 Prevention and Treatment. Zhejiang, China: Zhejiang University of Medicine.

Live Science (2020). Spanish Flu: The Deadliest Pandemic in History. Retrieved from https://www.livescience.com/spanish-flu.html on 14th July, 2020 at 10:07 pm.

Market Watch (2020). "Nigerian Air Force Confirms Killings of Over 300 Bandits in NW

Region". Xin Hua News. Retrieved from https://www.marketwatch.com/pressrelease/nigerian-air-force-confirms-killing-of-over-300-bandits-in-nw-region-202006-04 on 14th July, 2020 at 11: $52 \mathrm{pm}$.

National Centre for Disease Control (2020). COVID 19 Nigeria. Retrieved from https://covid19.ncdc.gov.ng/ on 14th July, 2020 at 10:12 pm.

Nwosu, C. (2017). Between Fulani Herdsman and Farmers: National Security underBuhari. The Republic. Retrieved from https://republic.com.ng/aprilmay2017/fulani-herdsmen-farmers/ on 14th July, 2020 at 9:42 pm.

Okoli, A.C. (2019). What Can be Done to Fight Rural Banditry in Northern Nigeria. Reliefweb. Retrieved from https://reliefweb.int/report/nigeria/what-can-be-donefight-rural-banditry-northern-nigeria on 14th July, 2020 at 11:23 pm.

Okoli, A.C., \& Ugwu, A.C. (2019). "Of Marauders and Brigands: Scoping the Threats of Rural

Banditry in North West Nigeria”. British Journal of African Studies. 4(8), 201-222.

Onwujekwe, O. Orjiakor, C. \& Agwu, P. (2020). "Coronavirus: corruption in health care could get in the way of Nigeria's response". The Conversation. Retrieved from https://theconversation.com/coronavirus-corruption-in-health-care-could-get-in-theway-of-nigerias-response-136913.

Orjinmo, N. (2020). "Katsina: The Motorcycle Bandits Terrorising Northern Nigeria". BBC News. Retrieved from https://www.bbc.com/news/world-africa-53009704 on 14th July, 2020 at 11:46 pm.

Osler, S. (2020). Corona Virus Outbreak. Revealed All Secrets About COVID 19 Pandemy. Complete Rational Guide It's Evolution, Expansion, Symptoms and First Defense. N.P.

Pichler, M., Skutnik, F., Vlad, A., Shahri, H., \& Ridwan, M. (2021). "Housing Price Index, Wealth, and Protective Shield against Covid-19". SIASAT Journal, 6(1), 1-8.

Rahmatirad, M. (2020). "A Review of Socio-Cultural Theory". Siasat. 5(3), 23-31.

Rosberg, A.G. \& Knell, R.G. (2020). How will this continue? Modelling Interactions Between the COVID-19 Pandemic and Policy Responses. London, UK: Queen Mary University of London. Available at CC-BY-NC-ND 4.0 International license.

Shaban, A.A. (2021). "Africa COVID 19 Stats. Africanews. Retrieved from https://www.africanews.com/2020/07/12/coronavirus-in-africa-breakdown-ofinfected-virus-free-countries/ on 14th July, 2020 at 11:58 pm. 
Sule, B., Azizuddin, M, Sani M., Mat, B. (2017). "Political Party Financing and Corruption in Nigeria'sFourth Republic: The Case of 2015 General Elections". Arts Social Sciences Journal 8: 298.

Sule, B., Ahmed, A., Alhaji, A., U., Yahaya, M., A., \& Gambarawa, K., I. (2019). "The Challenges of the Fight Against Insurgency in Northeastern Nigeria". Journal of Techno Social. 11(1), 7-15.

Suleiman, S. (2019). "Rural Banditry in Zamfara State: Northwest Nigeria". Social Science Research Council. Retrieved from https://kujengaamani.ssrc.org/2019/06/13/ruralbanditry-in-zamfara-state-northwest-nigeria/ on 14th July, 2020 at 11:27 pm.

Wang, L., Wang, Y., Ye, D., \& Liu, Q. (2020). "A Review of the 2019 Novel Coronavirus (COVID-19) Based on Current Evidence". International Journal of Antimicrobial Agents. Retrieved From https://doi.org/10.1016/j.ijantimicag.2020.105948 on 14th July, 2020 at 10:04 pm.

West Africa Network for Peace Building (2020). Addressing Armed Banditry in the North West Region of Nigeria: Exploring the Potentials of Multi-Dimensional ConflictManagement Approach. Abuja, Nigeria: WANEP.

Worldometers (2021). COVID 19 Corona Virus Pandemic: Corona Virus Cases. Retrieved from https://www.worldometers.info/coronavirus/ on 14th July, 2020 at 10:06 pm.

World Health Organisation (2021). African Countries Move from COVID 19 Readiness to Response as Many Confirm Cases. WHO Africa. Retrieved from https://www.afro.who.int/health-topics/coronavirus-covid-19 on 14th July, 2020 at 10:11 pm.

Zizek, S. (2020). Pandemic COVID 19 Shakes the World. New York: OR Books. 